\title{
Research on the Development of New Rural Sports in the Process of Well-off Society in China
}

\author{
DengHao \\ Zhengzhou finance and economics college sports success Zhengzhou 451200
}

Keyword: well-off society; countryside; sports.

\begin{abstract}
This paper taking the "new rural sports" under the context of building a well-off society in a full-around way as the research subject makes discussions on the functions, opportunities and existing problems etc of new rural sports by using the methods of documentation and logical analysis in order to promote the development of rural sports in the new period. The results show that the new rural sports is an important component of well-off society construction, which has outstanding value in the new rural culture construction, economic development as well as the shaping of new farmers. In the new period, the introduction of new rural construction policy and the development of rural economy, farmer's lifestyle as well as the sports industry have provided good improving platform for the rural sports. For the problems of weakening government management function, weak economic foundation, depressed culture atmosphere and other problems appeared in our current rural sports construction, it puts forward the suggestions of strengthening government management functions, expanding financing channels, building rural sports culture with characteristics and nurturing the main force etc.

In the report of the Sixteenth National Congress of the Communist Party of China $\left(16^{\text {th }}\right.$ NCCPC), it calls on to build our country into a well-off society at a high level that benefits over one billion people in 2020 through the joint efforts of all the national people. However, China is a large developing agriculture country and there are nearly $80 \%$ of the population lives in the countryside, so the rural problem is obviously becoming the core and difficult point in the full-around well-off society construction. In order to promote the rural economic and cultural development in a further way, it is clearly stated in the <The Eleventh Five-year Plan for National Economic and Social Development of the People's Republic of China> passed in the $4^{\text {th }}$ session of the $10^{\text {th }}$ National People's Congress to "build a new socialist countryside”, “develop rural culture undertakings” and "promote and implement peasants fitness project". It can be seen that in the process of building a well-off society in a full-around way, rural sports has become an important part of building well-off society and new socialist countryside. So how to develop a "new rural sports" that matches the construction of new socialist countryside is becoming a practical problem that needs urgent study and solution in our country. This paper aims to provide decisions and recommendations for the overall development of our current rural sports through the summarization and analysis of a series of related theoretical problems of new rural sports in the progress of well-off society and hopes that the exploration of this paper can have certain learning and promotion functions for the advancement of our current new rural sports.
\end{abstract}

\section{Position and Role of New Rural Sports in Building Well-Off Society.}

New Rural Sports-Important Symbol of New Rural Culture Construction and Development, Culture and Progress.

Rural sports is an effective way and important carrier of promoting rural material and spiritual civilization construction and with the high degree of civilization and lofty moral, it builds the spirit of people, sublimates the human thought, purifies human soul, inspires the fight will, improves the human quality and tempers man's will, which plays an important role in improving rural mental outlook, resisting ignorant and backward culture, enriching part-time cultural life, improving the farmer's quality, improving agricultural productivity levels, prospering rural economy and building a civilized and harmonious new socialist countryside. Just as indicated in the $2006<$ Views of CPC 
Central Committee and the State Council on Promoting the Construction of a New Socialist Countryside>, "to prosper rural culture, construct rural public cultural service system, promote and implement peasants fitness project, actively organize cultural activities that people loved, enjoyed and can learn something from it, protect and develop excellent traditional culture with local and national characteristics, carrier and methods of innovating rural cultural life”. It can be seen that, in the process of building a well-off society in a full-around way, new rural sport is not only the important content in the construction and development of new rural culture, but also the important symbol of new rural culture and progress.

New Rural Sports-Important Driving Force of New Rural Economic Development.

The promoting function of new rural sports to the new countryside economic developments is mainly expressed in the recessive and dominant two aspects. From the recessive point of view, rural sports can improve the farmers' physical quality, decrease the incidence of rural residents, enrich the part-time cultural life, promote mental health and improve the life quality. Indirectly create social wealth through decreasing medical expenses and improving the efficiency of agriculture production. Start from this point of view, there exist inner conjunction between the development of rural sports and the development of rural economy. From the dominant point of view, China's great rural population base has given birth to the giant potential sports consumers group. With the rapid development of rural economy, the sports concept of our farmers will definitely transfer from "welfare-oriented" to "consumer-oriented", which will be good for the formation of new rural sports consumption market and further promote the development of new rural sports industry and the related industries.

\section{Opportunities Faced by Our New Rural Sports in the Well-Off Society Construction.}

Build New Socialist Countryside; Provide Good Social Environment and Policy Support to the Development of Rural Sports.

As a great agriculture country, "agriculture, countryside and farmer” issues are always the basic issues of our social development and also the key points of building a well-off society in a full-around way. In order to realize the grand strategy of building the well-off society in a full-around way, our country clearly proposes requirements in the < Suggestions of CPC Central Committee on the Development of the Eleventh Five-year Plan on the National Economic and Social Development> to "build new socialist countryside", "develop rural cultural undertakings" and "promote and implement peasants' fitness project". At the same time, General Administration of Sport of China also formulated and issued <Views on the Implementation of Fitness Project for Peasants $>$ and it stipulates that sports departments at all levels should take the construction implementation of "Fitness Project for peasants" as an important task of long-term sports work both at present and in the future and it has been officially started in the nationwide in 2006. The "fitness project for peasants" takes the administrative villages as the main operation objects, the construction of village public stadium as the important point and builds the stadium around the peasants and cover the sports service system around the villages. The implementation of fitness project for peasants is good for easing the contradiction between peasants' increasing demand for fitness and the serious facilities deficiency of rural public sports ground, which provides favorable conditions for the prosperous development of rural sports.

The Development of Rural Economy and the Changes of Farmers' Lifestyle Have Improved Farmers' Need for Sports.

Since the reform and opening up, our rural economy has always been keeping at high-speed increasing trend and the living standards are improving gradually. Engel coefficient has decreased from $67.2 \%$ in 1978 to $47.2 \%$ in 2004 and the decreasing rate reached $20 \%$. The development of rural economy has made the past single farming way of life can not meet the farmers' needs gradually, while the seeking for mental enjoyment has become the inner yearning of peasants and there is an increasing demand for the sports among the farmers. For example, National Development and Reform Commission and General Administration of Sport of China have made research on the development situation of grass-roots sports in Ningxia, Shanxi, Zhejiang and other provinces. The research finds out that whether in South and North, grass-roots governments and farmers have already begun to make investment in the construction of rural sports facilities 
spontaneously and purchase sports device and get high enthusiasm in organizing sports activities. Affluent areas have built well-equipped rural sports stadiums while the less developed areas also make various kinds of sports activities based on whatever available.

\section{The Existing Problems of Our New Rural Sports Development in the Well-Off Society Construction.}

Reform of Rural Management System, Function Weakening of Grass-roots Sports Management Department.

Our rural management system reform implements "villages restructuring" and further causes the reform of township and town institutions. For example, in the 19 years between 1985 and 2004, the quantity of national townships (towns) has decreased from 91138 to 37334, totally decreased by 53804. In this process, the past township culture and sports center no longer exists and only set up culture service center, belonging to social service organization. Detailed to villages, because of villages merging and streamlining of village cadres, the number of personnel in village youth league, women's federation and militia groups has decreased from the former 3 to 2 with several roles. At the same time, many counties (districts) and townships (towns) also canceled the sports department, while they place it under other departments or merge or reorganize it with culture department, education department and health department etc. It weakens the permissions of grass-roots physical education department to a great extent, which weakens the grass-roots public sports, including the government management function of rural sports to some extent. For example, the research indicates that in the investigated townships (towns), the townships (towns) have no governing body for national fitness sports, no township cadres to be responsible for the sports work, no farmers sports association and other farmer sports organizations, which respectively take up by $52.3 \%, 47 \%$ and 63; in the investigated administrative villages, there is no village-level sports governing bodies, no village cadres to be responsible for the sports and no farmer sports organizations, which respectively take up by $84.3 \%, 74.8 \%$ and $86.9 \%$. In some individual provinces, the percentage of these "Nos" even exceeds $90 \%{ }^{[6]}$.

Increase of Rural Labor Migration Population, the Rural Sports Main Force has been weakened.

The result of the fifth population census shows that at present there are 88 million mobile population, most part of which are migrant workers. The statistics from National Bureau of Statistics shows that from 1978 to 2000, there are totally 130 million agricultural labor forces have been transferred to non-agriculture industries from China countryside and there are 5.91 million people have been transferred each year on average. Also the research of "Rural Labor Mobility Group” indicates that in the after few years, the newly increased workers in each year will not less than 8 million. Even considering about the backflow factors, the newly increased migrant workers will not less than 6 million. In the rural labor migrant population, the young and strong labor takes a vast majority and they are the backbone of rural sports. But stay away from home for many years; it weakens the main force of rural sports imperceptibly.

Economic Gap between Urban and Countryside Becomes Increasingly Prominent, Economic

\section{Foundation of Rural Sports is Weak}

"During the tenth five-year period", the central government issued a series of policies to benefit farmers and reform measures and the net income per capita of the rural residents has increased from RMB 2253 in 2000 to RMB 3255 in 2005, increased by RMB 1002 of 44.4\% and increased by $7.6 \%$ in the five years on average. Deduct the price factor, the real annual increase on average is $5.2 \%$, increased by $0.5 \%$ compared with the annual increase on average during the "ninth five-period" [9]. Although our rural economic construction has made some achievements, the long-term weak situation of our rural economic foundation has not got fundamental change. For example, the income ratio between urban and countryside residents has increased from 2.79:1 in 2000 to 3.22:1 in 2005 and the consumption ratio has increased from 2.99:1 in 2000 to 3.09:1 in 2005. The limitation of rural economic development directly affects the infrastructure construction of our rural sports. According to the statistics of the fifth national stadium census, till 2003, our nation has 850080 stadiums of all kinds that meet the fifth national stadium census requirements, but those of townships (towns) only have 66446, only taking $8.18 \%$ of the total amount. 


\section{Countermeasures And Suggestions For Promoting Our Rural Sports Development.}

Strengthen Government Sports Management Function.

Developing mass sports is the basic duty of people's governments at all levels. At present, the county people's government should make sure the township sports development goals and combine the sports work into the inspection content of evaluating the township cadre performances. Meanwhile, township government should integrate the sports into the overall planning of township national economic and social development, set up sports work leading team, farmers' sports association and elderly sports association etc, which should be leaded by the township main responsible comrades and set up culture and sports station (or sports station), equip culture and sports (sports) specialists, care for, support and supervise their work. For example, there is town sports commission in the towns of Pearl River Delta area and the sports commission works under the direct lead of town government and the positioning is also in the town government. This kind of commission can make the town sports work has the direct leading, participation and support from the town government and there are responsible people to actively perform the rural sports activities with good results.

Strengthen to Cultivate the Main Force of Rural Sports.

According to Xueyi Lu's classification for the social classes of the rural area in $<$ Research Report on Contemporary Social Classes in China>, the present countryside has been classified into 8 classes: agricultural laborers class, migrant workers class, employee class, farmer intellectual class, individual workers and individual business class, private entrepreneurs class, township enterprise managers class and rural administrator class ${ }^{[12]}$. On the whole, the relatively rich agriculture laborer and the subsistence agricultural labors in agricultural laborers class, the workers who do not do the farm work while do not leave the hometown in the migrant workers class, farmer intellectual class and rural administrator class are the most suitable to become the main force of rural sports. Therefore, it should make efforts to cultivate them into the main force of rural sports. Financing in a Multiple Way, Ensure the Normal Operation of Rural Sports.

On the capital investment, the county finance should correspondingly increase the funds for the rural sports with the economic and social development and strengthen the infrastructure construction of rural sports. Township (town) government should list the annual rural sports cost into the financial budget and increase annually. At the same time, each place should publish some preferential policies according to its own characteristics to encourage the enterprises, institutions, social communities and private entrepreneurs to actively participated in the investment and construction of public sports facility.

\section{Conclusion.}

The relationships among new rural sports, new countryside and well-off society are derived from the same origin. The construction of new socialist countryside can not be discussed without the development of "new rural sports". If the rural problems can not be solved, the well-off society can only be theoretically talking. Realize this clearly is good for correcting people's concept of rural sports and can provide the source of power for the development of new rural sports at the ideological level. While everything needs to experience a certain period for its improvement and development, completely change long-term backward situation of our rural sports can not be finished by overnight, it needs to be promoted with the political, economic and cultural construction simultaneously. Only through this way can the rural sports develop in a prosperous way.

\section{References}

[1] Marx, Engels. Selected Works of Marx and Engels [M]. Beijing: People’s Education Press, 1995, 32.

[2] Mei Ying Liu. Development Opportunity for Our Rural Sports [J]. Sports Culture Guide, 2007 (4): $9-12$ 